\title{
PENGEMBANGAN LEMBAR KERJA SISWA BERBASIS MASALAH DALAM MENINGKATKAN PEMAHAMAN KONSEP PADA MATERI EKOSISTEM KELAS VII MTS AL-MA'ARIF 2 MAYAMUK
}

\section{SUSANA LILI OI TUKAN ${ }^{1}$, ANANG TRIYOSO ${ }^{1}$, AZHARI RIDHO ${ }^{1}$}

${ }^{1}$ P. Biologi STKIP Muhammadiyah Sorong

Email: susanalilioi@ymail.com

\begin{abstract}
ABSTRAK
Penelitian ini bertujuan untuk mengembangkan lembar kerja siswa berbasis masalah dalam meningkatkan pemahaman konsep pada materi ekosistem. Penelitian ini dilaksanakan melalui pengembangan instrumen mengikuti rancangan 4-D model dari Thiagarajan (1974). Data hasil penelitian yang diperoleh sebagai berikut: hasil validasi instrumen LKS dalam kategori layak, reliabilitas petunjuk 94\%, relibilitas kelayakan isi 99\%, reliabilitas pemahaman konsep sains $100 \%$, reliabilitas prosedur 95\%, reliabilitas pertanyaan $96 \%$. keterbacaan instrumen menunjukan bahwa penampilan, isi, petunjuk, penjelasan dan tulisan pada LKS menarik dan sangat jelas dibaca. Keterlaksanaan pembelajaran berorientasi pemahaman konsep berkategori baik dengan nilai reliabilitas yaitu 99\%. Hasil analisis tes hasil belajar siswa yaitu nilai ketuntasan klasikal atau presentase yakni $83,3 \%$ dan rata-rata nilai pretest dan posttest siswa yaitu 45,8 dan 81,9 maka peningkatan pemahaman konsep siswa atau peningkatan hasil belajar siswa berhasil, minimal $60 \%$ dari jumlah siswa memperoleh nilai diatas 60 . Hambatan di lapangan adalah siswa belum terbiasa menggunakan instrumen LKS berbasis masalah. Berdasarkan hasil analisis data, dapat disimpulkan bahwa instrumen LKS berbasis masalah dalam meningkatkan pemahaman konsep siswa pada materi ekosistem yang dikembangkan valid, praktis, dan efektif.
\end{abstract}

Kata kunci : LKS, ekosistem, penelitian pengembangan

\section{ABSTRACT}

This study aims to develop students' problem-based worksheets in improving the understanding of the concept of the ecosystem material. This research was carried out through the development of an instrument to follow the design of the 4-D models Thiagarajan (1974). The data were obtained as follows: the results of the validation instruments BLM in the category of decent, instructions reliability 94\%, 99\% browse the reliability feasibility, reliability $100 \%$ understanding of science concepts, procedures reliability of $95 \%$, 96\% reliability questions. legibility of instruments shows that the appearance, contents, instructions, explanations and writing on LKS interesting and very clear to read. Enforceability of the learning-oriented understanding of the concept of well categorized with the value of reliability is $99 \%$. The results of the analysis of student achievement test that classical completeness or percentage value that is $83.3 \%$ and the average value of the students 'pretest and posttest 45.8 and 81.9, the increase in students' understanding of concepts or improving student learning outcomes successfully, at least $60 \%$ of the number of students scoring above 60 Obstacles in the field is that students are not accustomed to using problem-based worksheets instrument. Based on the results of data analysis, it can be concluded that the instrument in a problem-based worksheets increase students' understanding of the concept of the ecosystem material developed valid, practical, and effective.

Keywords: LKS, ecosystem, research development.

\section{PENDAHULUAN}

Pendidikan adalah suatu usaha yang dilakukan untuk mengembangkan kemampuan dan kepribadian individu melalui proses atau kegiatan tertentu (pengajaran, bimbingan atau latihan) serta interaksi individu dengan lingkungannya untuk mencapai manusia seutuhnya (insan kamil)" [1]. Oleh karena itu, pendidikan perlu digunakan dengan baik dan terencana agar dapat berhasil dengan harapan mencapai tujuan pendidikan yang efektif dan efisien.

Berdasarkan kurikulum KTSP (kurikulum tingkat satuan pendidikan), bahwa pembelajaran IPA yang diaplikasikan di SMP/MTs hendaknya dilaksanakan dengan pembelajaran terpadu. Hal ini seperti yang terkandung dalam lampiran Permendiknas No 22 Tahun 2006 tentang Standar Isi (SI) bahwa subtansinya untuk materi pelajaran IPA di tingkat SMP/MTs dilaksanakan secara terpadu untuk memperoleh kompetensi dasar ilmu pengetahuan dan teknologi serta membudayakan berpikir kritis, kreatif, dan mandiri. Pembelajaran berbasis masalah merupakan inovasi dalam pembelajaran karena dalam pembelajaran berbasis masalah kemampuan berpikir siswa betul-betul di optimalkan melalui proses kerja kelompok atau tim yang sistematis, sehingga siswa dapat memberdayakan, mengasah, menguji, dan mengembangkan kemampuan berpikirnya secara baik $^{[2]}$. Mengemukakan bahwa pembelajaran berbasis 
masalah membantu untuk meningkatkan perkembangan keterampilan belajar sepanjang hayat dalam pola pikir yang terbuka, reflektif, kritis, dan belajar aktif ${ }^{[3]}$. Betapa penting pemahaman konsep dapat dilihat dari dicantumkannya pemahaman terhadap konsep pada setiap kurikulum jenjang pendidikan. Di samping itu menurut penguasaan konsep adalah kemampuan seseorang yang dapat berbuat sesuatu $^{[4]}$.

LKS merupakan salah satu sarana untuk membantu dan mempermudah kegiatan pembelajaran, sehingga akan terbentuk interaksi yang efektif antara siswa dengan guru ${ }^{[5]}$. Pengembangan LKS memerlukan persiapan yang baik dalam perencanan materi dan tampilan untuk mendapatkan hasil yang optimal.

Proses pembelajaran yang berlangsung pun masih didominasi pada teacher centered. Anak didik kurang didorong untuk mengembangkan kemampuan berpikir. Pembelajaran di dalam kelas diarahkan kepada kemampuan anak untuk menghafal informasi. Otak anak dipaksa untuk mengingat dan menimbun berbagai informasi tanpa dituntut untuk memahami informasi dan menghubungkannya dengan kehidupan sehari-hari ${ }^{[6]}$. Guru menggunakan buku paket dalam proses pembelajaranya, tetapi pengembangan buku tersebut masih kurang sehingga kompetensi siswa harus ditingkatkan seoptimal mungkin. Dalam Lembar Kerja Siswa tersebut disusun untuk meningkatkan kemampuan pemahaman konsep pada pengetahuan siswa-siswi tersebut.

Tetapi kenyataan yang terjadi di sekolah, kebanyakan praktek pembelajaran masih menekankan pada kemampuan siswa untuk menyelesaikan soal-soal sedangkan kemampuan pemahaman konsep kurang diperhatikan hal ini menyebabkan para siswa cenderung menghafal konsep tanpa memahami materinya terlebih dahulu. Pembelajaran IPA seharusnya lebih banyak dilakukan dengan kegiatan praktikum di laboratorium. Faktanya peserta didik lebih banyak menghabiskan waktu untuk mengerjakan soal-soal dan menghafal konsep-konsep. Peserta didik cenderung cepat lupa apa bila diberikan konsepkonsep yang baru.

Berdasarkan latar belakang masalah di atas maka dapat dikemukakan rumusan masalah peneliti adalah "Bagaimana Pengembangan Lembar Kerja Siswa Berbasis Masalah dalam Meningkatkan Pemahaman konsep Siswa pokok materi Ekosistem pada kelas VII MTs Al-Ma'arif 2 Mayamuk"?

Mengingat banyaknya materi yang bisa dijangkau pada penelitian ini maka perlu adanya batasan penelitian. Materi pembelajaran dalam penelitian ini dibatasi pada materi Ekosistem.

Tujuan penelitian ini adalah pengembangan lembar kerja siswa berbasis masalah dalam meningkatkan pemahaman konsep siswa pada materi ekosistem.

Untuk kepentingan praktis, diharapkan dapat: Bagi siswa, hasil pengembangan berupa Lembar Kerja
Siswa ini dapat bermanfaat untuk meningkatkan pemahaman konsep siswa pokok materi Ekosistem. Bagi guru, Lembar Kerja Siswa ini diharapkan mampu memberikan inspirasi para guru untuk menerapkan pembelajaran IPA secara terpadu. Bagi sekolah, hasil penelitian ini dapat bermanfaat sebagai pertimbangan Lembar Kerja Siswa yang digunakan untuk para siswa. Bagi peneliti, segala proses yang ada dalam penyusunan penelitian ini akan menambah wawasan dan ilmu pengetahuan dalam pengalaman peneliti.

\section{METODE PENELITIAN}

Penelitian ini termasuk penelitian pengembangan (developmental research), karena mengembangkan Lembar Kerja Siswa (LKS) berbasis masalah pada mata pelajaran IPA materi Ekosistem. Instrumen lembar kerja siswa yang dikembangkan adalah instrumen berbasis masalah yang valid, praktis, dan efektif.

Sampel adalah sebagian atau wakil dari jumlah populasi yang diteliti ${ }^{[7]}$. Sampel dari penelitian ini adalah siswa kelas VII MTs Al-Ma'arif 2 Mayamuk dengan jumlah 24 siswa Tahun pelajaran 2013/2014 dengan menggunakan LKS berbasis masalah yang telah dikembangkan.

Alat atau Instrumen pengembilan data dalam penelitian ini dilakukan dengan metode yaitu:

Pemberian Tes

Metode pemberian tes yang dimaksud adalah metode pengumpulan data yang berupa lembar tes. Tes tersebut dikerjakan oleh siswa secara individu untuk mengetahui ketercapaian tujuan pembelajaran.

Metode observasi digunakan untuk menilai ranah psikomotor dan ranah afektif. Lembar observasi dilengkapi rublik penilaian yang digunakan sebagai acuan untuk menilai aktifitas siswa.

Metode pemberian angket digunakan untuk menilai keterbacaan siswa terhadap instrumen lembar kerja siswa yang digunakan. Angket diberikan kepada siswa untuk diisi pertanyaan-pertanyaan yang sesuai dengan pendapat siswa.

Bahan atau materi yang digunkan dalam penelitian ini adalah pelajaran IPA/Biologi pada pokok materi Ekosistem

Teknik pengumpulan data penelitian dalam penelitian ini adalah menggunakan model $4 \mathrm{D}$ (faour $D$ model) yang meliputi pendefinisian (define), perancangan (design), pengembangan (develop), dan penyebaran (disseminate) yang dikembangkan oleh [10]. Adapun tahap-tahap pengembangan instrumen adalah sebagai berikut :

Tahap Pendefinisian (Define)

Ditujukan untuk menetapkan dan mendefinisikan syarat-syarat pembuatan model pembelajaran dengan menganalisis tujuan dan materi pelajaran. Dalam tahap ini meliputi analisis muka-belakang, analisis siswa, analisis tugas, analisis konsep, dan spesifikasi tujuan pembelajaran. Analisis Muka Belakang adalah suatu langkah awal untuk mengetahui masalah dasar yang dibutuhkan dalam pengembangan instrumen lembar 
kerja siswa. Berdasarkan masalah tersebut maka dipilih alternatif lembar kerja siswa yang sesuai. Analisis siswa dilakukan untuk menelaah karekteristik siswa yang meliputi kemampuan akademik, usia, tingkat kedewasaan, pengalaman dan sebagainya. hasil analisis ini dijadikan gambaran untuk menyusun instrumen lembar kerja siswa berbasis masalah. Subyek dari penelitian ini adalah siswa kelas VII. Analisis konsep bertujuan untuk mengindentifikasi konsep-konsep utama yang akan diajarkan, menyusun secara sistematis dan merinci konsep-konsep yang relevan. Analisis konsep dilakukan dengan mengidentifikasi konsep-konsep untuk materi pembelajaran IPA/Biologi semester 2 kelas VII MTs Al-Ma'arif 2 Mayamuk. Analisis Tugas adalah kumpulan prosedur untuk menentukan isi satuan pelajaran. Analisis tugas dilakukan dengan merinci isi mata ajar dalam bentuk garis besar. Analisis ini mencakup :

Analisis struktur isi memuat kajian mengenai Standar kompetensi lulusan (SKL) sesuai Peraturan Menteri Pendidikan Nasional Nomor 23 Tahun 2006 dan standar isi yang terdiri atas Standar kompetensi dan kompetensi dasar SMP/MTs.

Analisis prosedur ditujukan untuk mengidentifikasi tahap-tahap penyelesaian tugas sesuai dikuasai siswa. Spesifikasi tujuan pembelajaran ini menggabungkan hasil analisis dari analisis tugas dan analisis konsep menjadi tujuan pembelajaran khusus yang selanjutnya menjadi dasar untuk penyusunan tes.

Tahap Perancangan (Design)

Tujuan dari tahap ini adalah untuk merancang instrumen lembar kerja siswa berbasis masalah, sehingga diperoleh prototipe (contoh instrumen lembar kerja siswa). Tahap ini dimulai setelah ditetapkan tujuan pembelajaran khusus. Kegiatan pada tahap ini adalah: Penyusunan lembar kerja siswa yang dilakukan dengan mengacu pada kompetensi dasar IPA/ Biologi semester 2 kelas VII MTs Al-ma'arif 2 Mayamuk. Penyusunan lembar kerja siswa diawali dengan menulis lembar kerja siswa dalam bentuk naskah, naskah ini kemudian dikonsultasikan para pakar. Hal ini dilakukan agar lembar kerja siswa yang disusun tidak ada kesalahan pada isinya. Ketika naskah tersebut terdapat kesalahan maka naskah segera diperbaiki dan setelah naskah tidak terjadi kesalahan maka akan dilanjutkan ke proses mendesain lembar kerja siswa. Menyusun lembar observasi, angket siswa, dan lembar validasi yang dilakukan dengan mengadaptasi dari berbagai sumber dengan tujuan agar diperoleh hasil yang maksimal.

Tahap Pengembangan (Development)

Tujuan dari tahap ini adalah untuk menghasilkan draf instrumen lembar kerja siswa berbasis masalah yang telah direvisi berdasarkan masukan para pakar dan data yang diperoleh dari uji coba.

Teknik analisis data merupakan suatu cara yang digunakan untuk menguraikan data yang diperoleh agar dapat dipahami bukan hanya oleh orang yang meneliti, tapi juga oleh orang lain yang ingin mengetahui hasil penelitian.

Untuk mengetahui bahwa lembar kerja siswa berbasis masalah dalam meningkatkan pemahaman konsep siswa valid, praktis dan efektif, diuji dengan menggunakan: Validitas lembar kerja siswa Lembar kerja siswa yang sudah dikembangkan selanjutnya dilakukan validitas petunjuk, kelayakan isi, pemahaman konsep sains, kemampuan memecahkan masalah, prosedur, dan pertanyaan oleh pakar sesuai dengan instrumen lembar kerja siswa. Data hasil validitas dianalisis secara deskriptif kualitatif. Dalam penelitian ini batas penerima adalah skor rerata $(\bar{X})$ dari hasil penilaian para validator kemudian ditentukan tingkat validitas intrumen yang dikembangkan dengan mencocokkan pada kriteria lembar kerja siswa sebagai berikut :

Tabel 1. Kriteria Pengkategorian Lembar kerja siswa

\begin{tabular}{|l|l|}
\hline Interval skor & Kategori penelitian \\
\hline $\bar{X}>4.65$ & Sangat layak \\
\hline $3.45<\bar{X}<4.64$ & Layak \\
\hline $1.15<\bar{X}<3.45$ & Sedang \\
\hline $0.35<\bar{X}<1.15$ & Kurang \\
\hline $\bar{X}<0.35$ & Rendah \\
\hline
\end{tabular}

( Diadaptasi dari Gronlund ${ }^{[1]}$ )

Tingkat keterbacaan merupakan ukuran dari pemahaman siswa terhadap LKS yang diuji cobakan. Angket keterbacaan LKS yang diberikan siswa dianalisis dengan menggunakan rumus deskriptif dengan presentase. Presentase keterbacaan siswa dihitung dengan cara; jumlah aspek yang muncul dibagi dengan seluruh jumlah respon siswa dikalikan 100.

Pengamatan keterlaksanaan pembelajaran dilakukan oleh pengamat yang sudah dilatih memberikan penilaian yang tepat. kriteria setiap fase pengamatan dinilai dengan memberikan tanda $(\sqrt{ })$ pada kolom keterlaksanaan (ya atau tidak) dan pada kolom penilaian (5 : sangat baik, 4 : baik, 3 : cukup baik, 2 : kurang baik, 1: tidak baik). Teknik analisis data secara deskriptif kuantitatif dengan teknik persentase.

Persentase keterlaksanaan menggunakan kriteria sebagai berikut:

Tabel 2. Kriteria Keterlaksanaan Pembelajaran

\begin{tabular}{|l|l|}
\hline Nilai $(\%)$ & Kriteria \\
\hline $80-100$ & Sangat baik \\
\hline $66-79$ & Baik \\
\hline $56-65$ & Cukup \\
\hline $41-55$ & Kurang \\
\hline $0-40$ & Gagal \\
\hline
\end{tabular}

Instrumen lembar kerja siswa yang telah divalidasi oleh para pakar dianalisis secara deskriptif 
kualitatif dan dihitung nilai reliabiitasnya menggunakan rumus sebagai berikut :

$R=1-\frac{A-B}{A+B} \times 100$

(3)

Keterangan :

$\mathrm{A}=$ frekuensi aspek yang akan dinilai oleh pengamat dengan memberikan frekuensi tinggi

$\mathrm{B}=$ frekuensi aspek yang dinilai oleh pengamat dengan memberikan frekuensi rendah

Instrumen dikatakan reliabel bila nilai relibilitas yang diperoleh $(\mathrm{R}) \geq 75 \%$

Pengertian pemahaman siswa adalah kemampuan untuk menangkap makna dan arti dari bahan yang dipelajari ${ }^{[13]}$. Pemahaman konsep siswa dalam pembelajaran IPA / Biologi berbasis masalah, diperoleh melalui uji presentase. Hal ini untuk memudahkan dalam menetukan hasil yang valid. Berdasarkan nilai yang diperoleh siswa dari pretes dan postes. Dalam penelitian ini data hanya dilihat menggunakan data dari ketuntasan siswa secara klasikal yaitu kelas dikatakan tuntas secara klasikal dalam kegiatan pembelajara yang telah dilakukan dan ketuntasan kelas tersebut mencapai $60 \%$.

setelah diperoleh nilai ketuntasan, peneliti menentukn kriteria skor rata-rata yang diperoleh siswa dengan menggunakan rumus:

$M=\frac{\sum X}{\sum Y}$

Keterangan :

M : Nilai Rata-Rata

$\sum \mathrm{X} \quad$ : Jumlah nilai

$\sum \mathrm{Y} \quad$ : Jumlah siswa

Pemberian kriteria bertujuan untuk mengetahui peningkatan pemahaman konsep siswa atau peningkatan hasil belajar siswa, kriteria yang digunakan adalah :

Tabel 3. Kriteria Penilaian

\begin{tabular}{rll}
\hline No. & Skor & Kriteria \\
\hline 1. & $8,5-10$ & Sangat tinggi \\
2. & $6,5-8,4$ & Tinggi \\
3. & $5,5-6,4$ & Sedang \\
4. & $3,5-5,4$ & Rendah \\
5. & $0-3,4$ & Sangat rendah \\
\hline
\end{tabular}

Penelitian ini dikatakan berhasil jika hasil belajar mata pelajaran biologi mencapai kriteria sebagai berikut : 1) Nilai rata - rata kelas siswa minimal mencapai 60,2$)$ Minimal $60 \%$ dari jumlah siswa memperoleh nilai diatas 60 .

Dengan demikian, apabila indikator keberhasilan tersebut telah tercapai, maka sekolah tersebut dapat dikatakan berhasil belajarnya meningkat dengan menggunakan pembelajaran IPA berbasis masalah.

Temuan hambatan-hambatan selama pelaksanaan pengembangan lembar kerja siswa berbasis masalah dan solusi alternatifnya untuk mengatasi hambatan yang muncul dilakukan oleh pengamat dan peneliti. Hasil pengamatan kemudian dicatat kedalam tabel pengamatan untuk dicarikan pemecahan yang dilgunakan pada kegiatan pengembangan LKS berbasis masalah, selanjutnya hambatan-hambatan tersebut dianalisis secara deskriptif kualitatif

\section{PEMBAHASAN}

Dalam penelitian ini, instrumen lembar kerja siswa berbasis masalah digunakan untuk mengukur pencapaian pemahaman konsep siswa pada semester genap kelas VII, pada penelitian ini kompetesi dasar yang diambil yakni 7.1 menentukan ekosistem dan saling hubungan antara komponen ekosistem.

Penyusunan Lembar Kerja Siswa berdasarkan tujuan pada rencana perangkat pembelajaran (RPP dan Silabus). Kemudian lembar keterbacaan Lembar Kerja Siswa (LKS) disusun dalam bentuk angket dan diujikan kepada siswa untuk menilai instrumen Lembar kerja Siswa (LKS), penilaian pendapat yaitu:1) menarik / tidak menarik, 2) mudah dimengerti / sulit dimengerti / sedang-sedang, 3) ada banyak / ada sedikit / tidak ada, 4) sangat jelas / tidak jelas. Selanjutnya lembar keterlaksanaan pembelajaran berorientasi pemahaman konsep dan lembar pengamatan afektif diamati oleh pengamat dengan menilai hasil pengamatan pada lembar tersebut pada saat proses pembelajaran berlangsung yang dilakukan oleh dua orang pengamat.

Validasi pakar dilakukan oleh dua pakar. Hasil telaah validator terhadap instrumen LKS berbasis masalah pada materi ekosistem. Hasil validasi dapat di lihat pada tabel 4. Dalam tabel hasil validasi tersebut diuraikan beberapa masukan dalam instrumen Lembar kerja siswa (LKS) yang memerlukan tindaklanjut (perbaikan) sebelum instrumen tersebut diterapkan dalam ujicoba.

Hasil validasi LKS menunjukkan bahwa validitas petunjuk mendapatkan nilai 4,25 (kategori sangat layak), validitas kelayakan isi mendapatkan nilai 4,10 (kategori sangat layak), pemahaman konsep sains mendapatkan nilai 3,75 (kategori layak), kemampuan memecahkan masalah mendapatkan nilai 3,25 (kategori layak), prosedur mendapatkan nilai 4,25 (kategori layak), dan pertanyaan mendapatkan nilai 4,16 (kategori layak), serta perhitungan hasil reliabilitas petunjuk sebesar 94\%, kelayakan isi sebesar 99\%, pemahaman konsep sains sebesar 100\%, kemampuan memecahkan masalah $92 \%$, prosedur sebesar $95 \%$, dan pertanyaan sebesar $96 \%$.

Penilaian keterbacaan instrumen LKS berbasis masalah dilakukan oleh 24 siswa kelas VII MTs AlMa'Arif Mayamuk yaitu, Sudrajat, Siti Munawaroh, Faisal Bisri, Irma Shintya, Nur Hamidah, Mochamad Shalman, Any Nuriyah, Sabrina Arlinda, Tutut Ayu Ningrum, Ma'arifvatul, Indah Nur Faidah, Nur Yahya, Fadil Abdulah, Ferdi Margo, Muh rahmat, Sahrul Ribadi, Lutfi, Icha Fandini, Arga Bahari, Devi Setiani, Abdul Manaf, Andre saputra, Andy, dan Arif. Hasil penilaian keterbacaan instrumen LKS berbasis masalah, $87 \%$ menyatakan bahwa penampilan LKS 
berbasis masalah ini menarik, $71 \%$ menyatakan isi LKS menarik, $76 \%$ menyatakan petunjuk pada LKS mudah dimengerti, $42 \%$ menyatakan penjelasan pada LKS ada sedikit yang sulit, $83 \%$ menyatakan bahwa tulisan pada lembar kerja siswa jelas dibaca.

Keterlaksanaan pembelajaran berorientasi pemahaman konsep pada materi ekosistem diamati oleh dua orang pengamat yang telah dilatih sebelumnya dengan menggunakan lembar keterlaksanaan pembelajaran. Adapun hasil keterlaksanaan pembelajaran kelas VII dapat dilihat pada tabel 5 dibawah ini.

Tabel 5. Hasil Keterlaksanaan Pembelajaran

\begin{tabular}{|l|l|c|l|}
\hline $\begin{array}{l}\text { No } \\
\text { - }\end{array}$ & $\begin{array}{l}\text { Aspek } \\
\text { yang } \\
\text { diamati }\end{array}$ & $\begin{array}{l}\text { Rata-rata } \\
\text { KBM (Y) }\end{array}$ & $\begin{array}{l}\text { Kriteria } \\
\text { keterlaks } \\
\text { anaan }\end{array}$ \\
\hline I & $\begin{array}{l}\text { Pendahulu } \\
\text { an }\end{array}$ & 4,2 & Baik \\
\hline II & Inti & 4,2 & Baik \\
\hline III & Penutup & 3,5 & Baik \\
\hline
\end{tabular}

Dari tabel di atas menunjukan bahwa keterlaksanaan pembelajaran berorientasi dengan mengunakan instrumen Lembar kerja siswa (LKS) kriteria keterlaksanaan baik. Instrumen dikatakan reliabel bila nilai reliabilitas yang diperoleh $(\mathrm{R}) \geq 75 \%{ }^{[14]}$. Berdasarkan hasil analisis keterlaksanaan pembelajaran berorientasi pemahaman konsep diperoleh reliabilitas pengamatan keterlaksanaan yaitu 99\%. Dengan demikian instrumen pengamatan keterlaksanaan pembelajaran berorientasi pemahaman konsep dalam kriteria baik. Dalam Pengamatan Keterlaksanaan Pembelajaran dilakukan pula pengamatan afektif dan pengamatan psikomotorik, dapat di lihat pengamatan afektif setiap siswa dari hasil yang di analisis menunjukkan bahwa $66-74 \%$ dalam kriteria baik. Hal yang sama pada pengamatan psikomotorik hasil yang diperoleh setiap siswa yaitu $67-77 \%$ dengan kriteria baik.

Untuk mengetahui hasil pemahaman konsep siswa, peneliti melakukan pretest dan postest. Hal itu dilakukan untuk mengetahui pemahaman konsep siswa dan bagaimana tingkat pemahaman konsep siswa terhadap materi yang disampaikan oleh guru tersebut. Adapun hasil pretest dan posttest siswa kelas VII MTs Al-Ma'arif 2 Mayamuk dapat dilihat pada tabel 6 dibawah ini:

Tabel 6. Hasil Analisis Tes Hasil Belajar

\begin{tabular}{|l|l|l|l|l|l|}
\hline $\begin{array}{l}\text { No } \\
\cdot\end{array}$ & $\begin{array}{l}\text { Nilai } \\
\text { pretes } \\
\text { t }\end{array}$ & $\begin{array}{l}\text { Jumlah } \\
\text { siswa }\end{array}$ & $\begin{array}{l}\text { Nilai } \\
\text { posttes } \\
\text { t }\end{array}$ & $\begin{array}{l}\text { Jumla } \\
\text { h } \\
\text { siswa }\end{array}$ & Gain \\
\hline 1 & 60 & 6 & 90 & 11 & 30 \\
\hline 2 & 50 & 6 & 80 & 6 & 30 \\
\hline 3 & 40 & 8 & 70 & 7 & 30 \\
\hline 4 & 30 & 4 & 60 & 0 & 30 \\
\hline
\end{tabular}

Dalam penelitian ini data dilihat menggunakan data dari ketuntasan siswa secara klasikal yakni ketuntasan kelas tersebut mencapai $60 \%$. Maka perhitungan menggunakan rumus : $\mathrm{KK}=\sum \frac{p}{n} \mathrm{x} 100 \%$

$$
\begin{aligned}
& \mathrm{P}=20 \\
& \mathrm{n}=24 \\
& \mathrm{KK}=\sum \frac{20}{24} \times 100 \% \\
& \mathrm{KK}=83,3 \%
\end{aligned}
$$

Setelah diperoleh nilai ketuntasan klasikal atau presentase yakni 83,3 \% maka peningkatan pemahaman konsep siswa atau peningkatan hasil belajar siswa berhasil, minimal $60 \%$ dari jumlah siswa memperoleh nilai diatas 60, Selanjutnya untuk menghitung nilai rata-rata pretest dan posttest dari keseluruhan nilai siswa dengan menggunakan rumus:

Keterangan :

$$
M=\frac{\sum X}{\sum Y}
$$

M : Nilai Rata-Rata

$\sum \mathrm{X} \quad$ : Jumlah nilai

$\sum \mathrm{Y} \quad$ : Jumlah siswa

Menghitung nilai rata-rata pretest

$$
\begin{aligned}
& M=\frac{1100}{24} \\
& =45,8
\end{aligned}
$$

Sedangkan hasil nilai rata-rata posttest adalah

$$
M=\frac{1960}{24}=81,6
$$

Jadi, hasil rata-rata tes pretest dan posttest siswa yaitu 45,8 dan 81,6. Dari hasil tersebut maka hasil pembelajaran meningkat dengan menggunakan berbasis masalah dengan kriteria penilaian tinggi.

Dengan demikian indikator keberhasilan tersebut tercapai, dan sekolah tersebut dikatakan hasil belajarnya meningkat dengan menggunakan pembelajaran berbasis masalah. salah satu hasil penelitian pengembangan adalah tersusun Lembar kerja siswa berbasis masalah mata pelajaran IPA/Biologi kelas VII pokok materi Ekosistem.

Lembar kerja siswa berbasis masalah yang dikembangkan, divalidasi oleh dua pakar, Berdasarkan hasil validasi yang dilakukan oleh pakar terhadap instrumen Lembar kerja siswa berbasis masalah yang dikembangkan, dapat diketahui bahwa instrumen yang dikembangkan sudah mencakup kriteria validitas, praktikalitas dan efektivitas.

Mendefinisikan penelitian pengembangan sebagai suatu pengkajian sistematis terhadap pendesainan pengembangan dan evaluasi program, proses dan produk pembelajaran yang harus memenuhi kriteria validitas, praktikalitas dan afektifitas ${ }^{[15]}$. Suatu produk atau program dikatakan valid apa bila ia merefleksikan jiwa pengetahuan (state-of-the-art knowledge). Cakupan validasi instrumen Lembar kerja siswa berbasis masalah dijabarkan dalam beberapa aspek yaitu aspek petunjuk, kelayakan isi, pemahaman konsep sains, kemampuan memecahkan masalah, prosedur, dan pertanyaan. Sedangkan keterbacaan instrumen LKS berbasis masalah ditinjau dari pendapat siswa.

Hasil validasi instrumen Lembar kerja siswa menunjukan bahwa validitas petunjuk LKS mendapatkan nilai 4,25 (kategori layak) dan hasil 
perhitungan reliabilitas petunjuk sebesar 94\%. Bahwa interprestasi $3.45<\bar{X}<4.64$ termasuk dalam kategori layak $^{[12]}$. Hasil tersebut menunjukan bahwa instrumen LKS layak digunakan sebagai alat ukur pencapaian proses pembelajaran yang digunakan reliabel dan memenuhi kriteria untuk diujicobakan kepada siswa. Hasil validasi LKS berbasis masalah menunjukan bahwa validitas kelayakan isi mendapatkan nilai 4,10 (kategori sangat layak) dan hasil perhitungan reliabilitas kelayakan isi sebesar 99\%. Interpretasi skor $3.45<\bar{X}<4.64$ termasuk dalam kategori layak ${ }^{[12]}$. Hasil validitas pemahaman konsep sains mendapatkan nilai 3,75 (kategori layak) dan hasil perhitungan reliabilitas pemahaman konsep sains sebesar $100 \%$, interpretasi skor $3.45<\bar{X}<4.64$ termasuk kategori layak. Hasil validitas kemampuan memecahkan masalah mendapatkan nilai 3,25 (kategori layak) dan hasil perhitungan reliabilitas sebesar 92\%. Hasil validitas prosedur mendapatkan nilai 4,25 (kategori layak) dan hasil reliabilitas sebesar 95\%, interpretasi skor $3.45<\bar{X}<4.64$ termasuk kategori layak. Hasil validitas pertanyaan mendapatkan nilai 4,16 (kategori layak) dan hasil reliabilitas sebesar 96\%, interpretasi skor termasuk $3.45<\bar{X}<4.64$ kategori layak.

Dari hasil validitas instrumen Lembar kerja siswa (LKS) maka dapat dinyatakan bahwa instrumen Lembar kerja siswa (LKS) layak untuk di uji cobakan kepada siswa untuk membantu dalam proses pembelajaran yang lebih baik.

Keterbacaan instrumen LKS dengan mengunakan lembar angket keterbacaan yang diberikan oleh pengamat kepada siswa untuk dijawab. Hal itu dilakukan untuk mengetahui keterbacaan LKS. Hasil penilaian keterbacaan instrumen Lembar kerja siswa berbasis masalah, $87 \%$ menyatakan bahwa penampilan LKS berbasis masalah ini menarik, $71 \%$ menyatakan isi LKS menarik, $76 \%$ menyatakan petunjuk pada LKS mudah dimengerti, $42 \%$ menyatakan bahwa penjelasan Lembar kerja siswa yang sulit sangat sedikit, $83 \%$ menyatakan bahwa tulisan pada Lembar kerja siswa sangat jelas dibaca. Hasil penilaian keterbacaan ini menunjukkan bahwa penampilan lembar kerja siswa (LKS), isi lembar kerja siswa menarik, petunjuk, penjelasan dan tulisan pada lembar kerja siswa mudah dipahami dan sangat jelas dibaca bagi siswa. Menjelaskan bahwa LKS merupakan salah satu bahan ajar yang paling penting untuk mencapai tujuan dari kegiatan pendidikan ${ }^{[16]}$.

Dalam penelitian ini kemampuan guru dalam mengolah pembelajaran dapat dilihat dari hasil pengamatan keterlaksanaan pembelajaran berorientasi pemahaman konsep. Aspek yang diamati terbagi ke dalam tiga bagian yaitu pendahuluan, inti dan penutup. Rata-rata hasil pengamat keterlaksanaan pembelajaran secara keseluruhan pada kelas VII termasuk dalam kriteria baik. Menunjukan bahwa pengamatan keterlaksanaan pembelajaran pada kegiatan pembelajaran berorientasi tersebut dapat dilaksanakan, selasai tepat waktu dan sistematis dan reliabilitas pengamatan keterlaksanaan dalam kriteria baik.
Sedangkan hasil pengamatan afektif setiap siswa yaitu mendapatkan nilai 66 - 74\% dengan kriteria baik, dari lima aspek yang diamati yaitu aspek disiplin dalam mengikuti kegiatan pembelajaran, jujur dalam mengerjakan Lembar kerja siswa (LKS), berpartisipasi aktif dalam diskusi kelompok, peduli terhadap apa yang disampaikan guru serta bertanggung jawab dalam mengerjakan tugas kelompok.

Pada pengamatan psikomotorik hasil yang diperoleh yaitu mendapat nilai $67-77 \%$ dengan kriteria baik. Pada ke empat aspek yang dinilai yakni siswa aktif dalam melakukan pengamatan, dapat mencari informasi dan literatur bersama kelompok, menyampaikan komunikasi lisan artinya bertanya kepada guru, berdiskusi dalam kelompok dan menyampaikan pendapat. Bahwa pembelajaran merupakan kegiatan komunikasi antara manusia, yaitu orang yang belajar (siswa) dan orang yang mengajar (guru), sedangkan siswa dapat melakukan identivikasi masalah ${ }^{[17]}$. Pembelajaran berbasis masalah merupakan suatu pendekatan pembelajaran yang menggunakan masalah dunia nyata sebagai suatu konteks bagi siswa untuk belajar tentang berpikir kritis dan ketrampilan pemecahan masalah serta untuk memperoleh pengetahuan dan konsep yang esensi dari materi pelajaran.

Mengungkapkan“Konsep "'sangat penting bagi manusia, karena digunakan dalam komunikasi dengan orang lain, dalam berpikir, dalam belajar, membaca, dan lain-lain ${ }^{[18]}$. Pemahaman konsep merupakan salah satu bentuk hasil belajar yang diperoleh siswa dalam mengikuti proses pembelajaran. Untuk mengetahui kesiapan siswa dalam kegiatan pembelajaran dan bagaimana tingkat pemahaman konsep siswa terhadap materi yang diberikan oleh guru, maka dilakukan tes, tes dilakukan melalui uji pretest dan posttest. Hasil pemahaman konsep siswa dilakukan dengan memberikan soal pretest yang dilakukan sebelum pembelajaran berlangsung dan soal posttest dilakukan pada akhir pembelajaran pada materi ekosistem. Hasil dari ketuntasan siswa secara klasikal yakni ketuntasan kelas tersebut mencapai $60 \%$. Setelah diperoleh nilai ketuntasan klasikal atau presentase yakni 83,3\% maka peningkatan pemahaman konsep siswa atau peningkatan hasil belajar siswa berhasil minimal 60\%, dari jumlah siswa memperoleh nilai diatas 60, jadi hasil pembelajaran siswa dengan menggunakan pembelajaran IPA Berbasis Masalah termasuk dalam kriteria penilaian tinggi. Kemudian rata-rata keseluruhan dari hasil pretest yaitu 45,8 sedangakan rata-rata keseluruhan hasil posttest yaitu 81,6. Dengan demikian tes hasil belajar siswa mengalami peningkatan dari hasil tes sebelumnya, hal tersebut terlihat pada hasil rata-rata tes. Sehingga dapat dikatakan bahwa hasil pembelajaran siswa meningkat pada materi ekosistem.

\section{KESIMPULAN}

Berdasarkan hasil penelitian dapat disimpulkan bahwa:

1. Pada keterbacaan siswa terhadap instrumen Lembar kerja siswa yaitu, penampilan Lembar kerja siswa 
$87 \%$ menarik, isi Lembar kerja siswa $78 \%$ menarik, petunjuk $76 \%$ mudah dimengerti, penjelasan yang sulit pada Lembar kerja siswa $42 \%$ ada sedikit yang sulit dan penulisan lembar kerja siswa $83 \%$ sangat jelas dibaca.

2. Lembar kerja siswa berbasis masalah, terlaksana dengan baik hal ini terlihat dari hasil pengamatan keterlaksanaan pembelajaran berorientasi pemahaman konsep dalam kriteria baik.

3. pada saat pemberian tes pretest hasilnya kurang maksimal sedangkan pada akhir pembelajaran (posttest) hasilnya mengalami peningkatan yang sangat baik, sehingga dapat dikatakan bahwa pemahaman konsep siswa sangat baik dari hasil sebelumnya.

4. Instrumen Lembar Kerja siswa berbasis masalah layak digunakan sebagai alat perangkat pembelajaran.

Daftar Pustaka

[1] Arifin, Zainal.. Penelitian Pendidikan. Bandung. PT Remaja Rosdakarya. 2012

[2] Tan, O. S.. Problem Based Learnin Innovation, Singapore: Seng Lee Press. 2003

[3] Margeston, Pembelajaran berbasis masalah. Bandung : alfabeta. 1994

[4] Gagne, dkk.. Principle of instructional desing holt Rinehart and wiston, Tallahassee. Florida 1988

[5] Devi, dkk. Pengembangan Perangkat Pembelajaran untuk Guru SMP. Bandung. 2009

[6] Sanjaya, Strategi pembelajaran berorientasi standar proses standar proses pendidikan.
Jakarta: Kencana Skripsi. Palembang: FKIP Universitas Sriwijaya. 2007

[7] Arikunto,S. Penelitian Suatu Pendekatan Praktik Prosedur,Jakarta: Rineka Cipta. 2006

[8] Sumadi.. Metodologi Penelitian. Jakarta: Rajawali Pers. 2003

[9] Soedjadi.. Kerawanan Pengajaran. Media Kencana. 1990

[10] Thiagarajan, Instructional Development for Training Teachers of Exceptional Children. Minnepolis: Indiana Universit. 1974

[11] Arikunto, S. Prosedur Penelitian Suatu Pendekatan Praktik. Edisi Revisi 6. Jakarta: Rineka Cipta. 2009

[12] Arikunto, Suharsimi. Dasar-dasar Evaluasi Pendidikan. Jakarta. 2013

[13] Winkel, W S. Psikologi Sosial. Penerbit Gramedia Widiasarana. Jakarta. Indonesia. 1996

[14] Depdiknas. Kurikulum Tingkat Satuan Pendidikan. Jakarta: Dikmenmun. 2008

[15] Rusdi, Andi. Pengembangan Perangkat Pembelajaran. blog at Wordpress.com. 2 April 2014. 2008.

[16] Kaymacki, S. A Review of Studies on Worksheets in Turkey. Jurnal of US-China Education. 2012

[17] Ratumanan. Pengantar penelitian ilmiah dasar, metode dan teknik. Bandung: Tarsito. 2002

[18] Nasution. Metode Research (Penelitian Ilmiah). Jakarta: Bumi Aksara. 2006

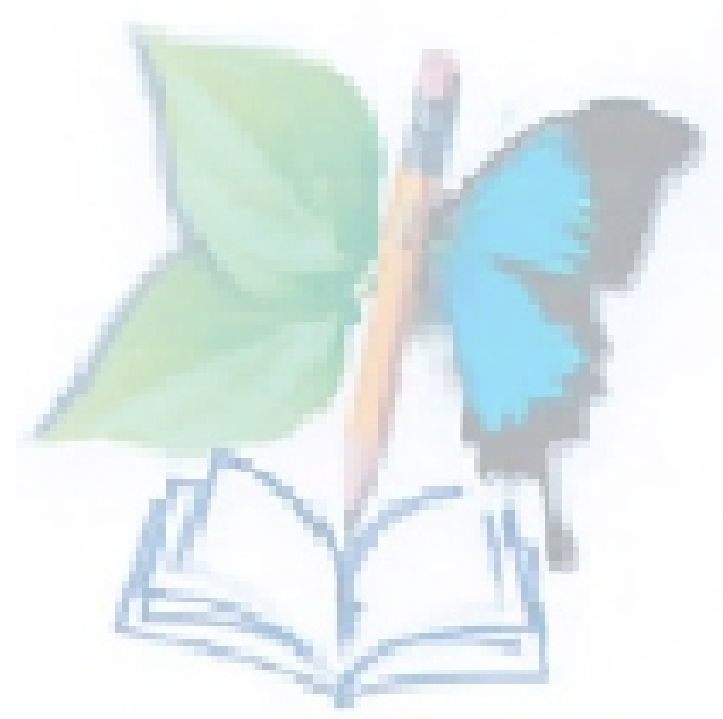

